\title{
Relationship of bacterial and viral infections to exacerbations of asthma
}

\author{
C W CLARKE
}

From the Department of Bacteriology, Cardiothoracic Institute, Brompton Hospital, London SW3 6HP, UK

ABSTRACT Fifty-one asthmatic patients were followed for up to 18 months. During this time 111 exacerbations of wheeze were recorded. Involvement by pathogenic respiratory bacteria and viruses was looked for directly by culture and indirectly by antibody studies. Proof of infection was found in only $12(10.8 \%)$ of the 111 exacerbations. Only eight patients provided sputum samples. Potential bacterial pathogens were found in four. Viruses were isolated in four of 27 exacerbation specimens; significant rises in specific viral antibody titres occurred in three. Six patients developed precipitating antibody to respiratory bacteria over the study but only one in relation to an exacerbation. The study therefore indicated that the great majority of exacerbations of asthma in these patients were not due to respiratory tract infection.

Infection is regarded as one of the factors precipitating exacerbations of asthma (Bruce Pearson, 1958; Swineford et al, 1962). Microbiological evidence to support this has been obtained in studies carried out in asthmatic children (Lambert and Stern, 1972; Horn et al, 1975; Minor et al, 1976) where viruses, particularly rhinoviruses, have been shown to be important. Only a few adults were looked at in these studies, and in the one of them in which it was possible to tell (Minor et al, 1976) difficulty was found in isolating agents from adult patients. Evidence for the association between infection and exacerbations of asthma in adults is not available.

In this study asthmatic patients with exacerbations of asthma were carefully investigated for objective evidence of bacterial or viral infection at the time of the exacerbation.

\section{Patients and methods}

Fifty-one patients with asthma attending an outpatient clinic at Brompton Hospital were studied (with informed consent) between March 1973 and December 1974. At the first study visit a complete history was obtained, physical examination performed, and peak flow rate and spirometry recorded.

Serum was tested for precipitating antibody to Haemophilus influenzae, Streptococcus pneumoniae, Staphylococcus aureus, Pseudomonas aeruginosa, and Klebsiella pneumoniae by immunodiffusion and immunoelectrophoresis (May, 1972). The presence of viral antibody against influenza $\mathrm{A}$ and $\mathrm{B}$, respiratory syncytial virus, adenovirus, and Mycoplasma pneumoniae was looked for by a microtitre complement-fixation test (Bradstreet and Taylor, 1962).

Each patient was asked to collect sputum (if any could be produced) in a sterile universal container on the morning of each following visit and to record on a diary card any exacerbation of wheezing together with associated symptoms.

Patients were seen every four to six weeks and as soon as possible after any exacerbations of wheezing. Details of the exacerbation were carefully checked with the patient and recorded. Appropriate treatment was instituted if necessary.

If a sputum sample was obtained it was assessed visually for purulence, then homogenised, cul- م tured, and the cell content examined (May, 1972). N Blood was collected for bacterial precipitins at $\mathcal{N}^{\circ}$ every visit and for viral antibodies at alternate $\omega$ visits. If a patient was seen less than five days after an exacerbation, or nasal symptoms per- $\stackrel{\varrho}{\subset}$ sisted at the time of the visit, nose and throat $\stackrel{\mathbb{D}}{\mathscr{D}}$ swabs were obtained and placed in Hank's transport medium. They were innoculated within three $\frac{T}{0}$ hours into cell cultures according to the method $\underset{\mathbb{D}}{\vec{D}}$ of Horn and Yealland (1974). Only those isola- $\frac{?}{\mathbb{D}}$ tions that were confirmed by neutralisation were $\unrhd$ included in the positive results. Rhinoviruses were 
serotyped by the Public Health Reference Laboratory, Colindale. After every exacerbation, viral antibody studies were performed including influenza $\mathrm{C}$, psittacosis, and $\mathrm{Q}$ fever in addition to those mentioned above. A fourfold rise in antibody titre in paired sera was regarded as evidence of recent infection.

\section{Results}

Fifty-one asthmatic patients with a mean age of 35.1 years $(\mathrm{SD} \pm 10 \cdot 8)$ were followed for periods of up to 18 months, a total of 604 patient visits. There were 28 women, of whom 15 were atopic, and 23 men, 16 atopic.

Forty-three patients had exacerbations of asthma during the period of observation resulting in a total of 111 exacerbations studied in detail. Symptoms associated with these are shown in table 1 .

Table 1 Symptoms associated with 111 exacerbations of asthma in 43 patients

\begin{tabular}{ll}
\hline Symptoms & No of exacerbations \\
\hline Nasal symptoms & 66 \\
Nasal obstruction & 27 \\
Rhinorrhoea & 31 \\
Sneezing & 22 \\
Sore throat & 50 \\
Chills or "fever" & 25 \\
Cough & 82 \\
Sputum & 69 \\
Sputum discoloured & 53 \\
\hline
\end{tabular}

EVIDENCE OF BACTERIAL INFECTION

Although sputum was stated to be a feature in 69 exacerbations, only 11 samples were produced from eight patients. Pathogens were grown from one sample from each of four patients ( $H$ influenzae (3) and Staph aureus (1)).

The number of patients with precipitating antibody to bacterial antigens at the start and at the end of the study is shown in table 2 . Six patients developed precipitating antibody to specific cytoplasmic antigen of $H$ influenzae during the study. One patient developed antibody to Str pneumoniae and two to Staph aureus. In only one patient could the development of precipitating antibody be related to an exacerbation and this was to $H$ influenzae. Precipitating antibody appeared in two patients who did not experience an exacerbation, in one to $H$ influenzae and one to Staph aureus. Once a patient developed precipitating antibody to antigen this persisted over the period of the study.
Table 2 Number of patients with antibody to bacterial antigens

\begin{tabular}{lcll}
\hline Bacterial antigen & $\begin{array}{l}\text { No with } \\
\text { precipitating } \\
\text { antibody at } \\
\text { start of study } \\
(51)\end{array}$ & $\begin{array}{l}\text { No with } \\
\text { precipitating } \\
\text { antibody at } \\
\text { end of study } \\
(51)\end{array}$ & $\begin{array}{l}\text { No who } \\
\text { developed } \\
\text { antibody during } \\
\text { study }\end{array}$ \\
\hline $\begin{array}{l}\text { Specific antigens of } \\
\text { H influenzae }\end{array}$ & $11 *(21 \cdot 6 \%)$ & $17(33 \cdot 3 \%)$ & $6 \dagger$ \\
$\begin{array}{l}\text { Str pneumoniae } \\
\text { Staph aureus }\end{array}$ & $14(27 \cdot 5 \%)$ & $15(29 \cdot 4 \%)$ & 1 \\
Ps aeruginosa & $22(43 \cdot 1 \%)$ & $24(47 \cdot 1 \%)$ & 2 \\
K pneumoniae & 0 & 0 & 0 \\
\hline
\end{tabular}

*Eight present or past smokers, three non-smokers.

†All present or past smokers.

EVIDENCE OF VIRAL INFECTION

Swabs for virus isolation were obtained in 27 of the 111 exacerbations. Four positive isolations were made $-H$ rhinovirus (3), Coxsackie B2 (1).

Paired serum samples were obtained after 102 of the exacerbations. The first sample was collected at a mean time after the onset of 13 days (range 2-23) while the second was collected at a mean time of 50 days (range 16-108). A further 190 samples were sent from routine visits. Evidence of viral infection was found in association with only four exacerbations-influenza A (2), influenza B (1), and adenovirus (1).

\section{Discussion}

The study was designed only to determine whether there is an association between exacerbations of wheeze in adult asthmatic patients and microbiological evidence of infection with bacteria or viruses.

Histories obtained at the time of an exacerbation indicated that increase in wheeze in an asthmatic subject is often associated with symptoms that may be clinically regarded as evidence of upper (Heath, 1973) or lower (Crofton and Douglas, 1975) respiratory tract infection or both. On clinical grounds alone, bacterial or viral infection would then be accepted as a common associated factor in the exacerbations studied. With the methods used in the study, however, evidence to support the association was found in only $12(10.8 \%)$ exacerbations.

Culture of the sputum produced yielded few pathogens. This agrees with the results obtained from similar studies on sputum (Arbesman, 1954; Dworetzky and Philson, 1968; Giraldo et al, 1969; Lambert and Stern, 1972) and transtracheal aspirate (Berman et al, 1975) in acute asthma. This would suggest that sputum production alone 
should not be regarded as evidence of microbial infection and does not support the widespread use of antibiotics in uncomplicated asthmatic patients.

Several patients were shown to develop precipitating antibody to bacterial antigen over the course of the study. The significance of this in the absence of a control group is uncertain, but it may be related to the patient's smoking history and be independent of their asthma, as the presence of specific antibody to $H$ influenzae has been shown to be strongly correlated with smoking habits in a large group of men (May et al, 1973).

The present study is in agreement with other studies that have failed to show evidence of bacterial infection in asthmatic patients (Glynn, 1959; Morgan and Wood, 1965; Burns and May, 1967, 1968; Burns, 1968a and b; BTTA, 1975; Davies et al, 1976). In fact, in these patients the frequency of precipitating antibody to the bacterial antigens used in this study was no different to that seen in a group of control subjects (Clarke, 1975).

The study looked at frequent intervals for antibody to several viruses known to be the important ones in the local environment. With this technique viral infection was diagnosed after only three exacerbations. Isolation techniques diagnosed a further four. The obvious reason for this is that a virus may not have caused the symptoms. Other possibilities are that the swabs may not have contained sufficient upper respiratory tract cells infected with virus or that the virus may not have survived transport to the laboratory. This would seem unlikely as standard reliable techniques were followed. The patient may have been seen at a time after the illness when the chances of obtaining an isolation were low. This is no doubt the case in some as isolation was attempted outside the first five days of the illness, but it was only attempted if upper respiratory tract symptoms persisted. The hospital setting may not have been the appropriate place to obtain this evidence and it emphasises the importance of studies carried out in the community (Lambert and Stern, 1972; Gregg, 1975; Horn et al, 1975). Despite this the study does suggest that these symptoms in an adult asthmatic subject do not always indicate viral infection.

With the methods used, proof of bacterial infection was found in five exacerbations and viral infection in seven; the difficulty of finding an infective agent in exacerbations of adult asthma is confirmed (Minor et al, 1976). Upper or lower respiratory tract symptoms occurring in association with an exacerbation of wheeze in an asthmatic patient should be regarded only as evi- dence of inflammation in that area. Infection may be just one of the causes of this. Labelling all $\stackrel{9}{\rightarrow}$ respiratory tract syndromes, particularly those 0 related to the upper airways as infective, with little objective evidence (Busse, 1977) adds little to our understanding of the problem and has $\stackrel{\triangle}{\triangle}$ implications with regard to initial treatment of an exacerbation.

I am grateful to the Board of Governors, National Heart and Chest Hospitals, Brompton, o for their financial support for the duration of this $\vec{x}$ study, the late Professor J R May, and Professor J Pepys, Mrs S Yealland, Mr P Taylor, Mr D E $\stackrel{+}{\dot{\omega}}$ Roberts, and Dr I Gregg.

\section{References}

Arbesman, C E (1954). Discussion. New York State Journal of Medicine, 54, 2691-2692.

Berman, S Z, Mathison, D A, Stevenson, D D, Tan, E M, and Vaughan, J H (1975). Transtracheal aspiration studies in asthmatic patients in relapse $\vec{\theta}$ with "infective" asthma and in subjects without $\bullet$ respiratory disease. Journal of Allergy and Clinical Immunology, 56, 206-213.

Bradstreet, C M P, and Taylor, C E D (1962). Technique of complement fixation test applicable to the diagnosis of virus diseases. Monthly Bulletin of the Ministry of Health and Public Health Laboratory $₫$ Service, 21, 96-104.

British Thoracic and Tuberculosis Association (1975). 윽 Immunological features of asthma (Part II). Clinical Allergy, 5, 403-416.

Bruce Pearson, R S (1958). Natural history of asthma. Acta Allergolica (Kbh), 12, 277-294.

Burns, M W (1968a). Precipitins to pneumococcal C- 음 substance polysaccharide in the serum of patients $\underset{x}{x}$ with chronic bronchial disorders. Lancet, 1, 223225.

Burns, M W (1968b). Precipitins to Klebsiella and $\delta$ other enterobacteria in the serum of patients with chronic respiratory disorders. Lancet, 1, 383-385.

Burns, M W, and May, J R (1967). Haemophilus influenzae precipitins in the serum of patients with $\frac{T}{O}$ chronic bronchial disorders. Lancet, 1, 354-358.

Burns, M W, and May, J R (1968). Bacterial pre- N cipitins in serum of patients with cystic fibrosis. Lancet, 1, 270-272.

Busse, W (1977). Decreased granulocyte response to isoproterenol in asthma during upper respiratory $\sigma$ tract infections. American Review of Respiratory Disease, 115, 783-791.

Clarke, C W (1975). A clinical and immunological study of infection in bronchial disease. PhD Thesis. University of London.

Crofton, J, and Douglas, A (1975). Respiratory $\frac{\vec{\Phi}}{\mathrm{D}}$ Diseases, 2nd edn, pp 80-81. Blackwell, Oxford.

Davies, R J, Holford-Strevens, V C, Wells, I D, and $\mathbb{D}$ Pepys, J (1976). Bacterial precipitins and their 0 immunoglobulin class in atopic asthma, non-atopic 
asthma, and chronic bronchitis. Thorax, 31, 419424.

Dworetzky, M, and Philson, A D (1968). Review of asthmatic patients hospitalized in the pavilion service of The New York Hospital from 1948-1963, with emphasis on mortality rate. Journal of Allergy, 41, 181-194.

Giraldo, B, Blumenthal, $M$ N, and Spink, W W (1969). Aspirin intolerance and asthma. A clinical and immunological study. Annals of Internal Medicine, 71, 479-496.

Glynn, A A (1959). Antibodies to Haemophilus influenzae in chronic bronchitis. British Medical Journal, 2, 911-914.

Gregg, I (1975). The role of viral infection in asthma and bronchitis. In Symposium Viral Diseases, edited by A T Proudfoot. Publication No 46, p 82. Royal College of Physicians, Edinburgh.

Heath, R B (1973). Virus infection of the respiratory tract. In Recent Advances in Medicine, edited by D N Baron, N Compston, and A M Dawson, 16th edn, p 181. Churchill Livingstone, London.

Horn, M E C, and Yealland, S J (1974). Significance of respiratory virus isolations. A study in primary school children. Archives of Diseases of Childhood, 49, 516-519.

Horn, M E C, Brain, E , Gregg, I, Yealland, S J, and Inglis, J M (1975). Respiratory viral infection in childhood. A survey in general practice, Roehampton 1967-1972. Journal of Hygiene, 74, 157-168.
Lambert, H P, and Stern, H (1972). Infective factors in exacerbations of bronchitis and asthma. British Medical Journal, 3, 323-327.

May, J $R$ (1972). Chemotherapy and Chronic Bronchitis and Allied Disorders, 2nd edn. English Universities Press, London.

May, J R, Peto, R, Tinker, C M, and Fletcher, C M (1973). A study of Haemophilus influenzae precipitins in the serum of working men in relation to smoking habits, bronchial infection, and airways obstruction. American Review of Respiratory Disease, 108, 460-468.

Minor, T E, Dick, E C, Baker, J W, Ouellette, J J, Cohen, M, and Reed, C E (1976). Rhinovirus and influenza type $\mathrm{A}$ infections as precipitants of asthma. American Review of Respiratory Disease, 113, 149 153.

Morgan, W K C, and Wood, W H (1965). Antibody response to Haemophilus influenzae in obstructive airway disease. Lancet, 1, 1128-1131.

Swineford, O jun, Johnson, E $\mathbf{R}$ jun, Cook, $H$ M jun, and Ochota, L (1962). Infectious asthma. An analysis of the asthmagrams of 100 cases and a critical review. Annals of Allergy, 20, 155-174.

Requests for reprints to: Dr C W Clarke, PO Box 310, Eastwood, NSW 2122, Australia.

\section{Siena Sarcoidosis Symposium}

\section{1-23 September 1979}

A Sarcoidosis Conference will be held in Siena under the direction of Professor Leopoldo Lenzini, Hospital for Respiratory Disorders, Siena, Italy. He will gladly provide further particulars. 